\title{
Wat Phra Tat: Space and Environment Management of Buddhist Temples and Relics in the Esan Region
}

\author{
Bancha Nakthong ${ }^{1}$, Sitthisak Jumpadaeng ${ }^{1} \&$ Souneth Phothisane ${ }^{1}$ \\ ${ }^{1}$ The Faculty of Cultural Science, Mahasarakham University, Khamriang Sub-District, Kantarawichai District, \\ Maha Sarakham Province, Thailand \\ Correspondence: Bancha Nakthong, The Faculty of Cultural Science, Mahasarakham University, Khamriang \\ Sub-District, Kantarawichai District, Maha Sarakham Province 44150, Thailand. E-mail: \\ bnakthong128@gmail.com
}

Received: June 10, 2014 Accepted: June 20, 2014 Online Published: September 22, 2014

doi:10.5539/ach.v7n1p16 URL: http://dx.doi.org/10.5539/ach.v7n1p16

\begin{abstract}
This qualitative investigation assesses the problems and conditions of space and environment management in nineteen temples of North-eastern Thailand. The results found that the current problems with management in the area are the ineffective division of space within the temple complex, the lack of systems to accommodate large influxes of people and the harm that overcrowding causes the temple environment. The research team outlined a method to combat these problems that consisted of temple space restructuring to make the grounds more suitable for large numbers of visitors, thus reducing strain on the environment. This was achieved by redistributing the land allocation and making the Phra Tat the most important feature of the temple, from which all other areas may be accessed. By ensuring that all visitors to the temple come into contact with the Phra Tat, this model will maximize the promotion of precious architectural and Buddhist heritage in Esan.
\end{abstract}

Keywords: management, Buddhism, temple, Esan, space

\section{Introduction}

In North-eastern Thailand, known colloquially as Esan, temples have held great importance as centres of the society and the community since their inheritance from Sri Lankan culture (Diskul, 1979). They are places that have grown with religion through the ages and facilitated its transmission from generation to generation. However, this is not the full extent of their historical role. In the past, temples were institutions for the implementation of religious duties and places of education. Temples provided help where it was needed, encouraged the development of art and represented stability in the area. The first temples contained wihan halls for meetings and worship. As time progressed, so accommodation was incorporated for the monks (Nakwatchara, 1982). The architecture of the temples can be classified into areas according to its role and importance for Buddhism. These classifications are the worship area (ked puttawat), the monastic area (ked sangkawat) and common area (ked brok). Most temples in Esan have loose restrictions for the division of these areas, with the exception of large city temples. Technically, the worship area contains the buildings used to practice religious rites and ceremonies, including the ubosot, the wihan, the bibliotheca for Buddhist scriptures, the bell tower, the drum tower, the bong tower and chedi housing sarira (Buddhist relics) and remains of descendants, monks and prominent people. The monastic area of the temple is designated for the living quarters of the monk and usually contains the monk cells and multipurpose halls. The common area is open space outside of the worship and monastic zones that is used for a variety of purposes, most commonly community ceremonies and festivals. This area contains the preceptor administration hall, cremation tower, pavilion for resting the coffin, commercial buildings, temple gates and temple walls (Noiwangklang, 2005). The temples are constructed in the vicinity of the community as they are believed to bring prosperity and fortune to the area.

The importance of the temples is clear in the Esan customs of the twelve months and worship ceremonies to pay respect to the Phra Tat. Phra Tatare relic-housing chedis and temples containing these structures carry greater importance (Wongthes, 2006). In the past, the temple was maintained under the authority of the community but as time passed, the government and state took over responsibility for the maintenance of the temples, so that they were considered government institutions. This had a negative influence on the use of space, relationships, temple patrons and care of religion. The ultimate consequence of these problems was the collapse of WatPhra Tat Phanom on $11^{\text {th }}$ 
August 1975. This event led to a government policy change regarding the temples and the introduction of a protected registry for ancient monuments. With this policy, Phra Tat Phanom was also moved under the authority of the Provincial Governor so that no further damage could be done to the dignity and surrounding environment of the temple. These problems were not limited to Phra Tat Phanom. Increased government participation in the running of Phra Tat Si Song Rak in Loei Province alienated the local people and caused difficulties with temple status, land administration, asset management, principles and methods of organizing ceremonies. Common people have a right to the treasures of the temples, as stipulated by the laws of the council of monks. For this right to be realised there must be effective management of the temple space to create a cultural heritage centre for the communities that have developed alongside the temple over time. The community has a right to use the temple space for their religious beliefs, mystical beliefs, commercial activities and, importantly, for tourism. There is an annual event to worship Phra Tat Phanom, which involves the participation of the government and private sector to boost the local economy through tourism. The difficulty is managing the temple space so that the activities held within are consistent and appropriate with the principles of Buddhism.

\section{Literature Review}

Buddhist temples are a valuable part of world heritage because their architecture reflects religious beliefs and their relationship with society (Snodgrass, 1985). This is a relationship that has changed over the course of time. Although the purpose of temple construction in Thailand has changed little over the course of two-hundred years, there has been a marked change in social perceptions of the temple due to a decline in people entering the monkhood and a decrease in central budget (Nakwatchara, 1982). Also cited as causing transformation of the temple from the centre of society to an ordinary member have been Western lifestyle influences, decrease in agricultural occupations, increased communication with external communities, increased external control and less dependence on nature (Nakwatchara, 1982; Promnart\&Tassanariporn, 2005; Wanlipodom, 1990). Despite this shift, no new spaces have been created to accommodate for modern communal interests (Iamsriwong, 2005) and the temple grounds that traditionally consist of the ubosot, the chedi, the wihan and habitation for monks (Jeeratassanakoon, 1994) have suffered (Nakwatchara, 1982).

Local Thai scholarship has focused on the structural and functional concepts of American theorist Talcott Parsons to explain the management of the temple as part of a social system (Parsons, 1961; Wannsiri, 1997). However, this outlook does not take into account the nature of the grounds as public space, which means that use of the temple is determined by ever-changing everyday lifestyle that must be examined in terms of the society it is in (Lefebvre, 1974; MacCannell, 1973; Madanipour, 1996; Pritchard \& Morgan, 2006). There have been a number of attempts to define space, which have resulted in three (Lefebvre, 2004) and four (Correa, 1989) categories being defined. Indeed, the space of Esan has a set of subcategories all to itself (Promnart\&Tassanariporn, 2005). Studies in the past have been aimed at determining and classifying the constituent parts of temple architecture (Kamwansa, 1999; Noiwangklang, 2005; Panin, 1995) or public space (Dumm, 2002; Foucault, 1967) separately. Cave (2005) also described a conceptual framework applying otherness as a management structure for tourism interactions, transactions and encounters. There have been a number of recent studies discussing the role of social and cultural space in holy places, its relationship with the community, the people and the use of local resources (Fuentes, 2010; Nesbitt, 2006; Waitt, 2003). However there has been little focus on the direct use of that space within the temple boundaries of Esan. In light of this, the research team was interested in studying the heritage management of temples containing Phra Tat, so to ensure that the use of space and resources was maximized to benefit the temples whilst remaining true to Buddhist principles.

\section{Methodology}

This was a qualitative research that employed in-depth study, document analysis and field research to gather data relating to space and environment management of Buddhist temples and relics in the Esan region of Thailand. The temples selected to be investigated as part of the research were chosen for their historical, cultural and religious significance to the people of North-eastern Thailand. A total of nineteen temples with Phra Tat were chosen for the field research, in accordance with five stipulations: a) the temple was located in the Esan region; b) the temple had correct allocation of wisungkhamasima. This means that the land for the central hall was provided by the King. They were also required to contain Phra Tat; c) the temple held historical significance for the local area or community; d) the temple was created or renovated in the artistic style of the Thai-Laos cultures; e) the temple was worshipped by the communities and local people. The research team is aware that this type of purposive non-probability sampling has been considered lacking by some scholars, such as Emily Stier Adler and Roger Clark, for generating samples that are 'unrepresentative of the population from which they have been drawn' $(2010,104)$. However, as Stier Adler and Clark go on to concede, purposive sampling is the most appropriate practice given such a specific population as Phra Tat temples in North-eastern Thailand. Indeed, purposive sampling is the best 
available technique because the research intentions are not to promote the samples at a representative level but rather to apply research theories and conclusions to the management of this specific group of temples (Potisitta, 2009). The following are the temples chosen for this investigation: Wat Ponechai, Loei Province; Wat Mahatat, Loei Province; Wat Phra Tat Bangpuan, Nong Khai Province; Wat Mahatat Chedi (Phra Tat Don Kaew), Udon Thani Province; Wat Phra Tat Choeng Chum, Sakon Nakhon Province; Wat Phra Tat Renu, Nakhon Phanom Province; Wat Phra Tat Phanom, Nakhon Phanom Province; Wat Phra Tat Nong Sam Meun, Chaiyaphum Province; Wat Chediyaphum (Phra Tat Kam Kaen), Khon Kaen Province; Wat Umangkala Nariang, Kalasin Province; Wat Neua (Tat Bu), Roi-Et Province; Wat Mahatat (Phra Tat Anon), Yasothon Province; Wat Gujan (Tat Gujan), Yasothon Province; Wat Na Phra Tat (Wat Daku), Nakhon Ratchasima; Wat Potsritat, Surin Province; Wat Phra Tat Rueang Rong (Wat Srang Rueang), Sri-Saket Province; Wat Ba Bueng Kao Luang, Ubon Ratchatani Province; Wat Tat Suantan, Ubon Ratchatani Province; Wat Phra Tat Nong Bua, Ubon Ratchatani Province. The temples selected for the study and their locations are illustrated in Figure 1 (Figure 1).

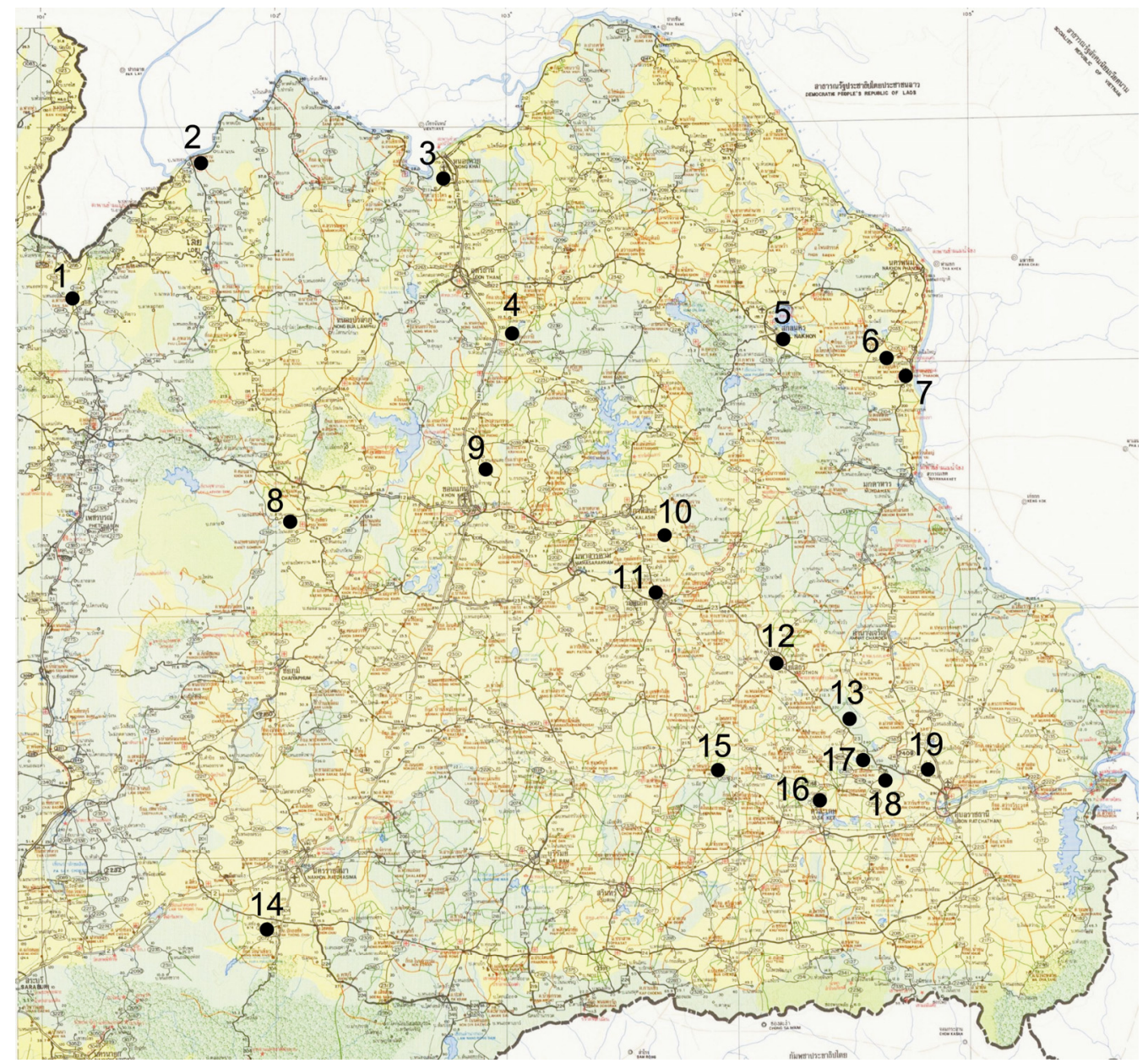

Figure 1. The locations of North-eastern Thai temples selected for this research

Key

1 Wat Ponechai, Loei Province

3 Wat Phra Tat Bangpuan, Nong Khai Province

5 Wat Phra Tat Choeng Chum, Sakon Nakhon Province

7 WatPhra Tat Phanom, NakhonPhanom Province

9 Wat Chediyaphum (Phra Tat Kam Kaen), Khon Kaen Province

11 Wat Neua (Tat Bu), Roi-Et Province

13 Wat Gujan (Tat Gujan), Yasothon Province

15 Wat Potsritat, Surin Province

17 Wat Ba Bueng Kao Luang, Ubon Ratchatani Province

19 Wat Phra Tat NongBua, Ubon Ratchatani Province
2 Wat Mahatat, Loei Province

4 Wat Mahatat Chedi (Phra Tat Don Kaew), Udon Thani Province

6 Wat Phra Tat Renu, Nakhon Phanom Province

8 WatPhra Tat Nong Sam Meun, Chaiyaphum Province

10 Wat Umangkala Nariang, Kalasin Province

12 Wat Mahatat (Phra Tat Anon), Yasothon Province

14 Wat Na Phra Tat (Wat Daku), Nakhon Ratchasima

16 Wat Phra Tat Rueang Rong (Wat Srang Rueang), Sri-Saket Province

18 Wat Tat Suantan, Ubon Ratchatani Province 
The research tools used for data collection were surveys, participatory and non-participatory observations and structured and non-structured interviews (Nontabatmadoon, 2003). The initial basic survey was used to gather general data relating to how each area, building and natural resource of the temple is used at different times. Observations and structured interviews were divided into three categories of questioning: general data, space usage and problems and surrounding environment and problems (Chuto, 2005). The aims of the interviews were to ascertain the thoughts of the population according to three research aims, which were to examine the background of space and environment of temples Phra Tat in Esan, to study the current conditions and problems of space and environment of temples Phra Tat in Esan and to investigate the management of space and environment of temples with Phra Tat in Esan. Members of the research population were divided into three groups for the collection of data. Group one was composed of selected experts in the field of Phra Tat and temple management from three areas, the government, the private sector and the community. The government experts were provincial governors from each province containing temples selected for research, municipal mayors from each temple area, leaders of community administration organizations in each temple area and the leaders of each temple. Private sector representatives were selected from tourism management groups, local businesses and religious instructors in areas containing the temples selected for research. The remainder of group one was made up by senior members of the communities surrounding the temples studied. Group two was composed of temple monks and people living around the areas of the temples studied. Group three was composed of people practicing religion at the temples, worshippers and tourists. The total number of informants used throughout this research was thirty-nine individuals. Data validation was conducted using four methods of triangulation: data triangulation validated the data by location, time and source; investigator triangulation validated the data according to researchers; theory triangulation validated the data against existing theories of temple management and space; methodological triangulation validated the data by research tool used for collection. The research period began in October 2010 and lasted a period of two years until October 2012.

\section{The use of Space and the Environment in Esan Phra Tat temples}

From observation of the research sites, there were three apparent trends of Phra Tat placement in the temple complexes. Five Phra Tat had been constructed at the front centre of the ubosot. These were at Wat Ponechai, Wat Phra Tat Bangpuan, Wat Umangkala Nariang, Wat Ba Bueng Kao Luang and Wat Phra Tat Nong Bua. Seven Phra Tat had been erected at the rear centre of the ubosot. These seven temples were Wat Mahatat Chedi (Phra Tat Don Kaew), Wat Phra Tat Choeng Chum, Wat Phra Tat Phanom, Wat Neua (Tat Bu), Wat Mahatat (Phra Tat Anon), Wat Gujan (Tat Gujan) and Wat Potsritat. Seven temples had constructed their Phra Tat to the side of the ubosot. These temples were Wat Mahatat, Wat Phra Tat Renu, Wat Phra Tat Nong Sam Meun, Wat Chediyaphum (Phra Tat Kam Kaen), Wat Na Phra Tat (Wat Daku), Wat Phra Tat Rueang Rong (Wat Srang Rueang), and Wat Tat Suantan. The current division of space in the temples is clearly defined into three zones, ked puttawat, kedsangkawat and kedbrok. In the first zone, ked puttawat, the space is used for religious activities, worship and rites. The zone contains the Phra Tat, ubosot and wihan. Around the Phra Tat is a wide area for the purpose of circling the structure during times of worship. The area is connected to the community in many directions and these entrances to the temple grounds depend on the layout of the surrounding environment. The main entrance to the temple is invariably the most convenient access for vehicles. The multipurpose hall is the location of general religious and community activities. On important days in the calendar, the temple grounds are central to the different activities held, causing the temple committees to consider expansion.

The Fine Arts Department has created a registry of ancient monuments and protected areas to conduct renovations and restoration projects under the care of the department. The temple areas themselves are kept clean by combined efforts from the temples and local communities. A big problem in some temples is the construction of structures that have not been given prior approval from the Fine Arts Department. This construction has had a negative effect on the ancient monument and the surrounding environment. Of the temples studied, a number have completed successful restoration programs that enhanced the beauty and environment of the ancient monuments, most notably Wat Phra Tat Nong Sam Meun, Wat Gujan (Tat Gujan), and Wat Chediyaphum (Phra Tat Kam Kaen).

The head of the monastery is responsible for delegating maintenance work and everyday tasks to monks and management of their participation with members of the temple committee. Regarding events and activities that are to be held on the temple grounds, the temple council will hold a meeting to prepare and delegate individual responsibilities. In the case of large festivals or important events, the private sector and government will also send representatives to oversee and control the distribution of benefits. As members of the Fine Arts Department registry, the temples have the additional assistance of department representatives to supervise maintenance and care of the temple. 
Interviews with informants made it clear that that the ked puttawat and ked sangkawat are the most important parts of the temple, with the former providing the foundation for the use of the latter. From analysis of the survey results, the research team was able to conclude four distinct groups of temples that are differentiated by the spatial relationship between the ked puttawat and kedsangkawat. The first group of seven temples was found to have its monastic area to one (any) side of the worship area. These temples were Wat Phra Tat Renu, Wat Chediyaphum, Wat Umangkala Nariang, Wat Neua, Wat Potsritat, Wat Tat Suantan and Wat Phra Tat Nong Bua. The second group of three temples located its living quarters on both sides of the worship area. The temples in this group were Wat Mahatat (Phra Tat Anon), Wat Gujan and Wat Na Phra Tat. The third group of four temples had monastic accommodation on two continuous sides of the worship zone. These four temples were Wat Ponechai, Wat Mahatat Chedi, Wat Phra Tat Choeng Chum and Wat Phra Tat Rueang Rong. In the final group of five temples, the ked sangkawat surrounded the ked puttawat on three consecutive sides. These temples were Wat Mahatat, Wat Phra Tat Bangpuan, Wat Phra Tat Phanom, Wat Phra Tat Nong Sam Meun and Wat Ba Bueng Kao Luang. The survey results found that temples with their monastic area located on just one side of the worship area (group one) had the clearest and simplest division of grounds. This led to easy maintenance of the site and gave an overall impression of order (Phrakhru Kasem Punyapiram, personal communication, 2011). The smallest group of temples (group 2) had living quarters scattered on two different sides of the worship area. This method of space management was found to be the least effective and least suitable. 'The primary reason is the lack of clarity over which side of the monastic zone should be used for what purpose' (Phrakhru Banpotworakit, personal communication, 2011). Moreover, any contact between sides requires traversing the holy worship zone, which is not appropriate. Overall, the lack of continuously similar space provides a disorderly atmosphere.

From the current use of space in the temples, a number of general problems could be discerned. The vast majority of problems with the temples only occur at times of festivals and on important days in the calendar. On occasions such as the Songkran Festival in April, many visitors will come to the temples at the same time. This influx of people puts considerable strain on resources and facilities because the temples become overcrowded. 'The biggest source of problems is traffic' (PhramahaTonwicha, personal communication, 2011). The large numbers of people means large numbers of vehicles, which cause air pollution, sound pollution and traffic congestion. By parking in the temple grounds, the transportation also spoils the local scenery and prevents visitors from appreciating the full majesty of the temple architecture. A further problem is the heat in the uncovered temple grounds, although this is a year-round concern (Phrakhru Sriratanalangkorn, personal communication, 2011). The situation is not helped by the decision of some temple committees to pave the area around the Phra Tat with concrete, which retains the sun's heat.

\section{Space Management Design for Phra Tat Temples}

The research team considered the results obtained from observations, surveys and interviews and designed an appropriate method of space and environment management for temples containing Phra Tat in the Esan Region of Thailand. The temple space should be arranged in the clearest, simplest manner that allows continuous zones. The recommendation from this investigation is to designate three areas: public, semi-public and private. The public space is the area in which all visitors to the temple are welcome, with no restrictions. The semi-public space is the area in which all people may enter but rules and regulations must be obeyed. The private space is the area that visitors to the temple may not enter without prior permission. Trees must be planted throughout the temple complexes in order to create shade and combat the problem of excessive heat in the daytime. Open spaces must be covered with natural materials that do not retain heat. There are two suggested possibilities for the layout of the temple buildings. The first is a linear model that will allow the visitors to appreciate the importance of each structure. The visitor must pass each building to reach the next, which will enhance the sense of holiness generated by the temple grounds and architecture. The second model is bi-linear. The disadvantage here is that the visitor may bypass certain areas of the temple; however this is countered by the added sense of width and space in the temple.

The worship area should be considered the most significant part of the temple and is the zone that houses the Phra Tat, wihan and ubosot. This is supported by Somkid Jeeratassanakoon (1994), whose studies of Thai temples showed that the ked puttawatand ked sangkawat have had a mutual relationship in temple designs since the Sukhothai Kingdom in the thirteenth century. Importantly, Jeeratassanakoon's analysis of temple blueprints revealed that there were no cases where the ked sangkawat obstructed the entrance to the ked puttawat. Accordingly, this study places importance on the ked puttawat. In this model, the Phra Tat is surrounded by grounds for worshippers to circle the chedi during their rituals and ceremonies. These grounds are the link to other areas of the temple. In this way, all visitors to the temple must pass the Phra Tat. The entrance to the temple is the best link for vehicles to reach the ked puttawat. This research recommends two preferred models of 
management for the space relationship between the Phra Tat and the ubosot, linear and bilinear. This preference is shared by Ornsiri Panin (1995), whose study of building management in temples of Thailand drew the conclusion that the Phra Tat and ubosot should either be built one behind the other or next to one another. The first is a linear setup in which the Phra Tat and ubosot are located on the same plane (Figure 2). The second choice is bilinear, with the Phra Tat and ubosot side-by-side (Figure 3). Although the research identified three current space relationships between the ubosot and Phra Tat in each temple, it must be noted that the first and second group are both linear. The first group of temples placed the Phra Tat in front of the ubosot, while the second had the Phra Tat to the rear. In the recommended model defined here, the order of buildings is considered flexible as any changes to this order would be impractical. Parking space should be allocated at the front of the temple outside the three temple zones in order to combat the problems created by excessive traffic.

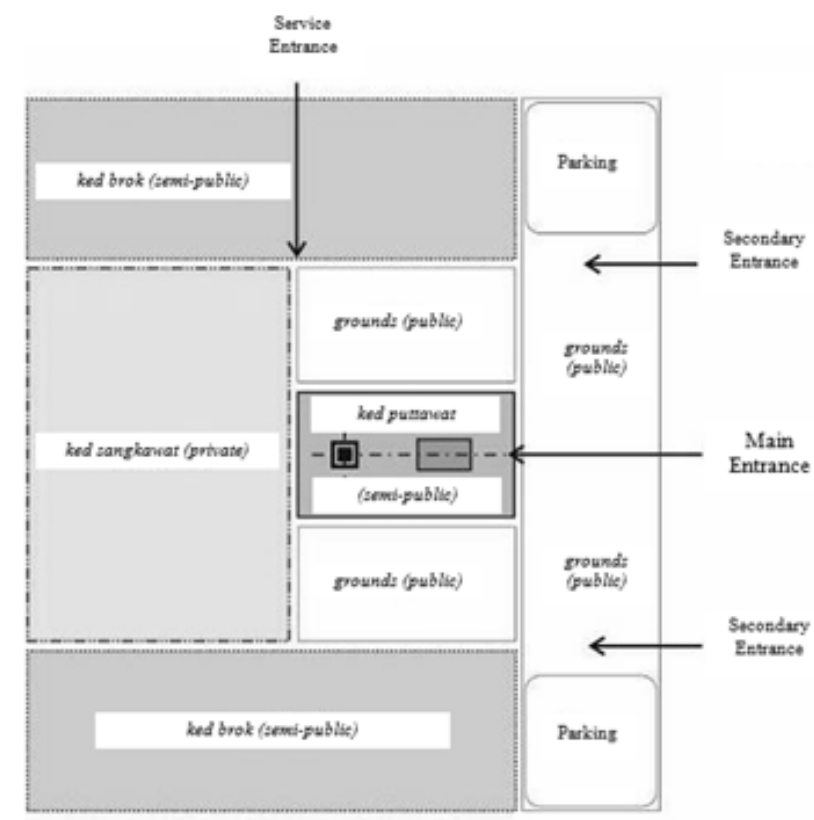

Figure 2. Suggested model of space management in Phra Tat temple complexes with the Phra Tat and the $u b o s o t$ in a linear position

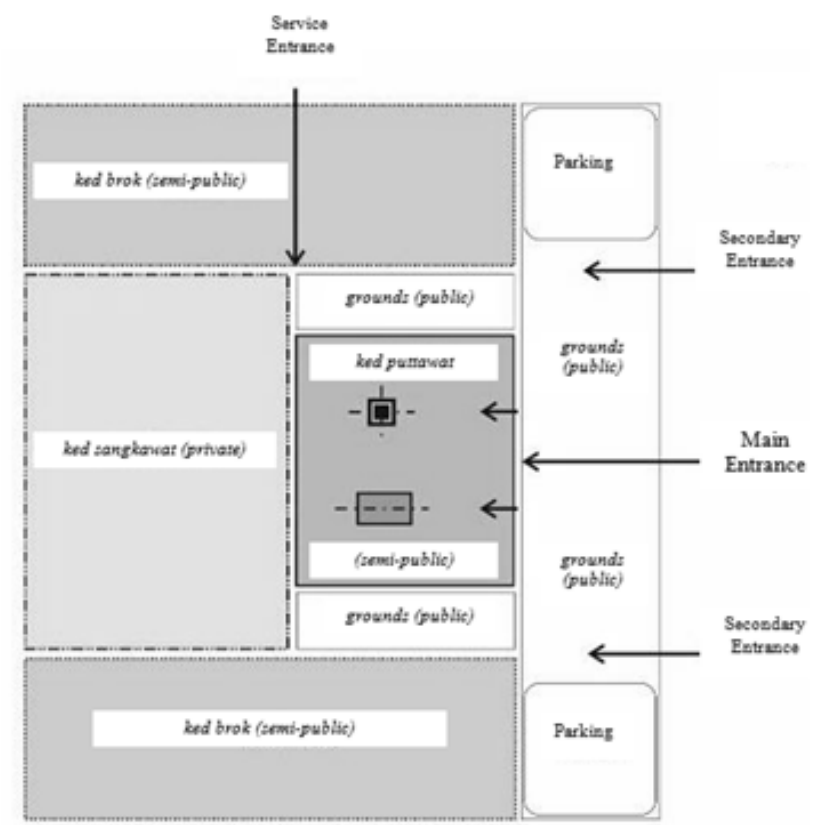

Figure 3. Suggested model of space management in Phra Tat temple complex with the Phra Tat and the $u$ bosotin a bilinear position 
As the temple grounds are used for a variety of activities, the management of the grounds should be considered in terms of both positive and negative space (Lefebvre, 1974; Madanipour, 1996). The positive space is the area that is consistently used throughout the year and should be covered with permanent shelter. The negative space is for unspecified activities that take place at certain times throughout the year, notably the busy festival periods. In the negative spaces, roofing is not necessary, although temporary structures may be considered. The positive space is primarily the ked puttawat, which contains the Phra Tat and ubosot.

The management committee designated to oversee cleaning, maintenance and general administration should consist of monks, community representatives and local administration organizations. This committee will have four responsibilities: define objectives and procedures to achieve those objectives, adapt, integrate different agencies and manage tensions. For the model outlined in this research, the composition of the temple management committee must include the three aforementioned members at a minimum. The committee must be presided over by the chief monk at the temple, as is currently the case. At times of festival, the committee may be expanded to accommodate extra tasks.

\section{Conclusion}

This research of space and environment management of Buddhist temples and relics in the Esan Region was a qualitative research that studied nineteen temples in North-eastern Thailand. Data was collected by document analysis, field research, interviews and observation and showed that monks take care of the buildings and inside the temple. A management committee was set to regulate the use of space and the environment. During ceremonies, the committee participates with the community to manage temple activities to benefit the temple, visitors and the local community. During major festivals the temple spaces are crowded, polluted and hot. Problems arise from the large number of people and quantity of cars entering the temple. In general, the environmental and building conditions were good with shady trees throughout the grounds, although some temple areas covered by concrete were hot during day time. The current division of space is into three areas for worship, living and common grounds. The divisions are often unclear and inappropriate.

The model outlined by this research suggests restructuring of the temple complex so that the ground is divided into public, semi-public and private spaces. The worship area is the most important part of the temple and the main entrance to the complex should provide the best access to that zone. All other areas of the temple should be accessible from the worship area. Inside the worship area, the Phra Tat (chedi) and ubosot (ordination hall) must be positioned either side by side or one in front of the other. This is to maximize the visitor impression of the temple architecture and sense of holiness and heritage. Parking space should be allocated at the front of the temples, trees must be planted in areas with no shade and concrete paving should be replaced with cooler, natural substances. With the implementation of this model by local authorities as a management policy for the Phra Tat temples it is hoped that this cultural heritage of North-eastern Thailand may continue to be appreciated by locals and tourists alike.

\section{References}

Boonotok, T. (1999). Indigenous Esan (History of Esan). Cultural Encyclopaedia of Thailand, Esan, Book 9 [in Thai]. Bangkok: Siam Commercial Bank.

Cave, J. (2005). Conceptualising 'otherness' as a management framework for tourism enterprise. In C. Ryan, \& M. Aicken (Eds.), Indigenous Tourism - the Commodification and Management of Culture (pp. 315-334). Oxford: Pergamon.http://dx.doi.org/10.1016/B978-0-08-044620-2.50023-7

Chuto, N. (2005). Qualitative research [in Thai]. Bangkok: Print Pro.

Correa, C. (1989). New landscape. Oxford: Butterworth-Heinemann.

Diskul, S. (1979). History of Southeast Asia until 2000BE [in Thai]. Bangkok: The Secretariat of the Cabinet, The Prime Minister's Office, Thailand.

Dumm, T. (2002). Michel Foucault and the politics of freedom. New York, NY: Rowman and Littlefield.

Foucault, M. (1967). Of other spaces: Heterotopias. Retrieved from http://foucault.info/documents/heterotopia/ foucault.heterotopia.en.html

Fuentes, A. (2010). Natural cultural encounters in Bali: Monkeys, temples, tourists, and ethnoprimatology. Cultural Anthropology, 25(4), 600-624.http://dx.doi.org/10.1111/j.1548-1360.2010.01071.x

Iamsriwong, N. (2005). The trouble with life [in Thai]. Bangkok: Matichon.

Jeeratassanakoon, S. (1994). Temples: The architecture of Buddhist institutions [in Thai]. Bangkok: Thammasat 
University Press.

Kamwansa, S. (1999).History of Buddhism in Thailand [in Thai]. Bangkok: Jaransanitwong.

Lefebvre, H. (1974). La production de l'espace [The production of space]. Paris: Anthropos.

Lefebvre, H. (2004). Rhythmanalysis: Space, time and everyday life (In G. Moore Trans.). London: Continuum.

MacCannell, D. (1973). Staged authenticity: Arrangements in social space in a tourist setting.American Journal of Sociology, 79(3), 259-603.http://dx.doi.org/10.1086/225585

Madanipour, A. (1996). Design of urban space: An Inquiry into a socio-spatial process. Chichester: John Wiley.

Nakwatchara, N. (1982). Temples in Bangkok: 200 years of change (1782-1982) [in Thai]. Bangkok: Chulalongkorn University Press.

Nesbitt, E. (2006). Locating British Hindus' sacred space.Contemporary South Asia, 15(2), 195-208. http://dx.doi.org/10.1080/09584930600955309

Noiwangklang, P. (2005). The social space in the tourist destinations of Northeast Thailand [in Thai]. Humanities and Social Sciences, 24(1), 88-97.

Nontabatmadoon, K. (2003). Qualitative research in social welfare: Research Concepts and Methods [in Thai]. Bangkok: Thammasat University Press.

Panin, O. (1995). Humanity and the creation of architecture [in Thai]. PathumThani: Rangsit University Press.

Parsons, T. (1961). Theories of society: Foundations of modern sociological theory. New York, NY: Free Press.

Potisitta, C. (2009). The science and art of qualitative research [in Thai]. Bangkok: Ammarin.

Pritchard, A., \& Morgan, N. J. (2006). Hotel Babylon? Exploring hotels as liminal sites of transition and transgression. Tourism Management, 27(5), 762-772.http://dx.doi.org/10.1016/j.tourman.2005.05.015

Promnart, S., \&Tassanariporn, B. (2005).Public space in Thai-Loei communities [in Thai].KhonKaen University Research Journal, (1041), 79-86.

Snodgrass, A. (1985). The symbolism of the stupa. New York, NY: Cornell University, Southeast Asia Program.

Stier Adler, E., \& Clark, R. (2010). An invitation to social research: How it's done. Stamford, CT: Cengage Learning.

Waitt, G. (2003). A place for Buddha in Wollongong, New South Wales? Territorial rules in the place-making of sacred spaces.Australian Geographer, 34(2), 223-238. http://dx.doi.org/10.1080/00049180301733

Wanlipodom, S. (1990). The meaning of royal Tat in the Siamese civilization (2nd ed.) [in Thai]. Bangkok: MueangBoran.

Wannsiri, N. (1997). Humanity, society and culture [in Thai]. Bangkok: Kasetsart University Press.

Wongthes, S. (2006). Suwannaphum: The start of a common Thai history [in Thai]. Bangkok: Matichon.

\section{Copyrights}

Copyright for this article is retained by the author(s), with first publication rights granted to the journal.

This is an open-access article distributed under the terms and conditions of the Creative Commons Attribution license (http://creativecommons.org/licenses/by/3.0/). 